\title{
CONTROLE DAS LICITAÇÕES PELO TRIBUNAL DE CONTAS
}

\author{
JORGE ULISSES JACOBY FERNANDES*
}

1. Sustação de atos da licitação. 2. Exame dos editais pelo Tribunal de Contas. 2.1. Prazo para solicitar editais para exame. 2.2. Exame de editais. 2.3. Solicitação para exame. 3. Direito de representar ao Tribunal de Contas. 4. Sustação de Contratos Administrativos pelos Tribunais de Contas. 5. Efeitos do exame pelo Tribunal de Contas. 6. Princípios e diretrizes vetoriais da ação do controle sobre licitação. 6.1 Princípio da aderência a diretrizes e normas. 6.2. Princípio da ampla defesa e do contraditório. 6.2.1 Direito de informação. 6.2.2 Direito de manifestação. 6.2.3 Direito de ver suas razões consideradas. 6.3. Diretriz da definição de responsabilidade. 7. Conclusões.

Uma nova perspectiva na nobre missão dos Tribunais de Contas vem se desvendando no controle das licitações públicas, capaz de permitir não só o controle da legalidade, quanto da legitimidade e da economicidade dos atos de gestão; capaz de revelar que os Tribunais de Contas podem muito mais do que efetivar o controle da despesa em favor do erário, mas impor-se definitivamente como instrumento para proteção da ordem jurídica, inclusive em favor do particular contratado pela Administração Pública. Uma ação do Tribunal de Contas capaz de, a um só tempo, controlar a corrupção e a malversação dos recursos públicos, resgatar a boa fé nas relações entre particulares e os gestores públicos, reduzir o volume de demandas judiciais, satisfazendo o interesse da sociedade de ver os recursos públicos bem aplicados.

Para justificar essa nova perspectiva e compreendê-la no modo e âmbito jurídico devido, mostra-se conveniente estudá-la dividindo em cinco temas, conforme segue.

* Mestre em Direito Público, autor de várias obras na área de Direito Administrativo, entre as quais Tribunal de Contas do Brasil - Jurisdição e Competência. a obra mais completa sobre Tribunais de Contas escrita em língua portuguesa.

R. Dir. Adm.,

Rio de Janeiro, 239: 95-110,

Jan./Mar. 2005 


\section{Sustação de atos da licitação}

O poder de sustar ato, no modelo delineado pela Constituição Federal, foi permitido a órgãos não integrantes do Poder Judiciário, de dois modos distintos. Ao Poder Legislativo foi atribuída a competência de sustar atos normativos que exorbitem do poder regulamentar ou dos limites da delegação legislativa ${ }^{\perp}$.

Conquanto tenha atribuído ao Poder Legislativo competência para sustar atos decorrentes do poder normativo, o constituinte não lhe outorgou poderes para sustar atos individuais e concretos, originariamente. Preferiu atribuir essa competência ao Tribunal de Contas ${ }^{2}$.

Ao definir essa competência, no entanto, impôs um inter para satisfazer o sistema de checks and balances, ou limitações recíprocas de poderes.

Desse modo exigiu que:

a) o Tribunal de Contas tenha impugnado o ato;

b) a Administração Pública, ciente da impugnação, não tenha atendido a ordem da sustação;

c) diante da recusa, o Tribunal de Contas suste diretamente o ato;

d) após ordenar a sustação, o Tribunal de Contas comunique a decisão à Câmara dos Deputados e ao Senado Federal.

Sendo o processo licitatório uma série ordenada de atos, qualquer um deles pode ser sustado pelo Tribunal de Contas. Essa competência é originária da Corte de Contas, dispensa a participação de qualquer órgão dos demais poderes e não pode ser exercida originariamente por qualquer deles de ofício. Como se trata de competência originária e constitucional, estendida a todos os Tribunais de Contas das unidades federadas ${ }^{3}$, o Poder Legislativo comunicado da decisão não tem o poder de rever o ato de sustação. Somente pode fazê-lo o Poder Judiciário, nos limites da ampla revisibilidade judicial dos atos frente à $\mathrm{Lei}^{4}$, e ainda assim somente pode agir mediante provocação.

\section{Exame dos editais pelo Tribunal de Contas}

A Lei de Licitações e Contratos ${ }^{5}$ estabeleceu que ao Tribunal de Contas compete o controle das despesas decorrentes dos contratos e demais instrumentos regidos por essa Lei, sem prejuízo do sistema de controle interno.

Essa competência, definida em nível infraconstitucional se insere no amplo espectro de competências que decorrem da própria Constituição Federal, quando permite o controle das despesas tanto em termos de contas anuais, como especiais, ou a aplicação de recursos públicos em geral.

1 Constituição Federal: art. 49. inc. V.

2 Constituição Federal: art. 71, inc. X.

3 Constituição Federal: art. 75.

4 Constituição Federal: art. $5^{\circ}$, inc. XXXV.

5 Lei 8.666, de 21 de junho de 1993. 
A divulgação do edital, como ato isolado de divulgação, tem por principal consequiência dar início à fase externa do processo licitatório, assegurando daí em diante o direito público subjetivo de todos quanto participem da licitação ao fiel cumprimento da Lei ${ }^{6}$. Somente com a publicação que revela a concretização do interesse de contratar, é que o Tribunal de Contas pode solicitar para exame o edital.

\subsection{Prazo para solicitar editais para exame}

Há duas e distintas consequiências segundo o tempo que o Tribunal de Contas fizer a solicitação. Se o edital for solicitado para exame até o dia útil imediatamente anterior à data de recebimento das propostas, os órgãos ficam obrigados a adoção das medidas corretivas pertinentes que, em função desse exame, lhes forem determinadas. O cumprimento da determinação é compulsório e pode implicar em reabertura do prazo para elaboração das propostas, total ou parcialmente ${ }^{7}$.

Se o edital, contudo, for solicitado para exame após essa data, a norma não esclarece se haverá obrigação de corrigir o edital. Há uma explicação lógica e jurídica para a não definição pela Lei. É que entre a data de recebimento das propostas, normalmente seguida da abertura e julgamento, poderá ter-se firmado direito subjetivo de terceiro, licitante-vencedor, que nesse caso pode comparecer para a defesa do ato convocatório. Recebida a proposta, o terceiro estará envolvido na relação, fato que implica na possibilidade de firmar-se o contraditório, restringindo a unilateral força cogente para adaptar o edital à Lei.

\subsection{Exame de editais}

No Brasil vigorou até a Constituição Federal de 1967 o sistema do registro prévio, obrigando-se até então o prévio exame da despesa pelo Tribunal de Contas e o registro da mesma, antes do pagamento. Com a abolição do sistema, o controle das despesas passou a ser posterior. Desse modo não é possível impor ao Tribunal de Contas ou mesmo este órgão pretender que para a validade da licitação seja previamente examinado o edital ${ }^{8}$.

Pela Lei de Licitações e Contratos o exame e a aprovação do edital competem ao órgão jurídico da respectiva Administração Pública ${ }^{9}$.

\subsection{Solicitação para exame}

Também definiu a norma que o Tribunal de Contas deve solicitar para exame, não cabendo portanto a ordem genérica para remeter todos os editais. Há que ser um a um, cada vez que ocorrer a publicação. Afinal, é consabido que o controle que

6 Lei $n^{\circ} 8.666 / 93$ : art. $4^{\circ}$.

7 Lei $\mathrm{n}^{\circ} 8.666 / 93$ : art. $21 . \S 4^{\circ}$.

8 Nesse sentido, a súmula $\mathrm{n}^{\circ} 78$ do TCU, publicada no DOU de 16.12.1976.

9 Lei $n^{\circ} 8.666 / 93$, art. 38, parágrafo único. 
se faz por transcrição e remessa de documentos aos órgãos de controle está felizmente com seus dias contados. Primeiro, porque quem transcreve ou copia a informação fica com o poder de apresentar informações fidedignas ou não e, por corolário, a ação de controle permanece nas mãos do controlado; segundo, por princípio que chegou a ser colocado em Lei, não cabe ao órgão controlador impor obrigações ao controlado, criar novas tarefas ou deveres, sob pena de inverter as proposições lógicas estruturantes do serviço passando a atividade fim trabalhar para a atividade meio, no caso o controle.

\section{Direito de representar ao Tribunal de Contas}

Interessante verificar que ao consagrar expressamente essa competência para controlar a despesa e examinar editais, o legislador definiu contornos mais acentuados para o exercício, não só resguardando a ação ex-officio da própria Corte de Contas, mas apontando no sentido do controle social. Foi mais longe, mostrou que o Tribunal de Contas pode se efetivar como Casa de Esperança ${ }^{10}$ permitindo que o próprio licitante que teve um direito seu lesado ou ameaçado recorra também a essa Corte, diretamente, sem a necessidade da intervenção de advogados, em mais um exercício do jus postulandi.

Atribuiu a competência para representar ao Tribunal de Contas a:

a) qualquer licitante;

b) qualquer contratado;

c) qualquer pessoa física; e ainda a

d) qualquer pessoa jurídica.

Essa representação guarda peculiaridades, segundo o agente que pretende exercitá-la.

De fato, quando se trata de licitante a própria norma impôs uma restrição ao direito de representar que está inserido no art. 41 da Lei $\mathrm{n}^{\circ} 8.666 / 93$ e facilmente se percebe pela leitura do final dos $\S \S 1^{\circ}$ e $2^{\circ}$, quando ao regular o direito de impugnar o cidadão ressalva que este permanece com o direito de representar ao Tribunal de Contas, na forma do respectivo art. 113.

Diferentemente, porém, dispôs em relação ao licitante definindo que se esse não representa à Administração Pública sobre irregularidades no edital, no prazo definido em Lei, decai do direito de representar perante o Tribunal de Contas.

Essa assertiva faz florescer um postulado importante na relação jurídica que o licitante entretém com a Administração Pública: o vetusto, mas não menos atualíssimo princípio da boa fé, ou no seu matiz processual: lealdade processual.

Se é verdade que o edital é lei entre as partes, elaborado pela Administração Pública, não é menos verdade que se encontra sujeito a um atípico controle da legalidade: antes de vincular a Administração Pública e o próprio licitante o edital

10 Expressão que se atribui ao Ministro Carlos Velloso, empregada no I Congresso Nacional dos Procuradores do Ministério Público junto aos Tribunais de Contas, realizado, Brasília. 
sujeita-se a possibilidade de ser impugnado pelos licitantes e, ainda, revogado ou anulado pela Administração. Decorrido esse prazo estabelecido pela Lei, presume-se o consentimento de todos os envolvidos no processo licitatório a subjugarem-se à regra particular do certame, assumindo pois a condição de lei entre as partes. ${ }^{11}$

Se o licitante decidir representar após ter caído o direito, compete aos Tribunais de Contas declarar a preclusão do direito de representar, sem prejuízo de eventual exame ex-officio. Certamente, contrariaria a Lei e o princípio da lealdade processual acolher representação de licitante que tendo tempo para fazê-lo de modo a maximizar os esforços da Administração e a redução de custos para as partes do processo licitatório, extemporaneamente pretende obviar a própria licitação. ${ }^{12}$ Daí também infere-se a razoabilidade jurídica dos acórdãos e sentenças que dão maior amplitude do que a expressamente decorrente de interpretação literal e vêem entendendo que o também ocorre decadência do direito de discutir norma do edital após decorrido o prazo legal para impugnação. ${ }^{13}$

Importa notar que muitas vezes ocorre de o licitante a pretexto de insurgir-se contra determinada conduta da comissão de licitação estar discutindo regra de edital. Portanto, imprescindível a cautela: ao receber a representação deve-se considerar exatamente o objetivo do licitante e impor um limite à matéria em discussão: no curso do processo licitatório, após decorrido o prazo de impugnação não mais se discute a legalidade das regras do edital; é possível, no entanto, discutir a aderência da conduta dos membros da comissão de licitação à regra posta.

Incentivando o controle social, e diversamente do exposto em relação ao licitante, a Lei de Licitações e Contratos não estabeleceu restrições temporais ao cidadão para representar ao Tribunal de Contas; poderá fazê-lo a qualquer tempo.

\section{Sustação de Contratos Administrativos pelos Tribunais de Contas}

Diversamente dos poderes que concedeu aos Tribunais de Contas, em relação a atos administrativos em geral, o constituinte, ao tratar de contratos, definiu ${ }^{14}$ uma

11 Lei n 8.666/93: art. 41: A Administração não pode descumprir as normas e condições do edital. ao qual se acha estritamente vinculada.

$\S 2^{\circ}$ Decairá do direito de impugnar os termos do edital de licitação perante a Administração o licitante que não o fizer até o segundo dia útil que anteceder a abertura dos envelopes de habilitação em concorrência, a abertura dos envelopes com as propostas em convite, tomada de preços ou concurso, ou a realização de leilão, as falhas ou irregularidades que viciariam esse edital, hipótese em que tal comunicação não terá efeito de recurso.

12 TCU: Decisão n⿳ 328/1996-Plenário, Proc. $n^{\circ}$ TC-275.039/1996-0. No mesmo sentido, TCU: Decisão $n^{\circ}$ 405/1996. Plenário; Proc. nº TC-275.077/1996-9.

13 TJDF: 4a Turma Cível, AC e REO n 19980110172126, DJU 27.08.2003. No mesmo sentido: STJ, ROMS $n^{\circ}$ 15.051, DJU de 18.11.2002.

14 No início do século, ao tempo do registro prévio. os contratos eram “julgados" pelo Tribunal da União. BRASIL. Decreto $n^{\circ} 2.511$, de 20 de dezembro de 191: Regula a Tomada de Contas ao Governo pelo Congresso Nacional. Coleção de Leis do Brasil 1911, v. 001, p. 00080, c.1, art. $5^{\circ}$. 
sistemática que envolve essas Cortes, o Poder Legislativo e o Poder Executivo, numa efetiva aplicação da teoria de freios e contrapesos cheks and balances.

Sustar um contrato significa retirar-lhe a eficácia, a produção dos efeitos financeiros, pagamento, por exemplo - e executivos — realização do objeto.

$\mathrm{O}$ inciso $\mathrm{X}$ e $\S \S 1^{\circ}$ e $2^{\circ}$ do art. 71 , da Constituição Federal, ao referir-se à sustação admitiu, implicitamente, que a mesma tivesse natureza cautelar ou definitiva.

Terá natureza meramente cautelar, quando determinada no curso de um processo visando resguardar o patrimônio público; natureza decisória definitiva quando for anunciado pelo Tribunal de Contas, com a recomendação para adotaras medidas legais, genericamente, ou implicar em providências incompatíveis com a continuidade do contrato.

Tecnicamente, nesse último caso, estará o Tribunal de Contas determinando a autoridade administrativa que anule o contrato. $\mathrm{Na}$ função de controle externo é possível determinar à autoridade que adote as providências "visando ao exato cumprimento da Lei", expressão essa comum no âmbito das recomendações dos Tribunais de Contas.

Assim, embora tecnicamente a recomendação para sustação em caráter definitivo não seja adequada, é possível entender que a competência constitucional para sustar assuma tal conotação, hipótese em que terá por corolário lógico a anulação ou rescisão.

Ao receber a comunicação para sustar o contrato, cabe a autoridade administrativa optar pela medida que melhor se harmonize com o interesse público. Divergindo da decisão, poderá impetrar recurso perante o próprio Tribunal ou iniciar a ação judicial pertinente.

Concordando, verificará se a sustação deverá ter natureza cautelar, corrigindo/sanando o contrato, ou definitiva, rescindindo ou anulando-o.

O Tribunal de Contas não pode sustar contrato, mas lhe é implícito o poder de determinar a Administração que o faça.

O ordenamento jurídico brasileiro, formado pela Constituição e lições do Supremo Tribunal Federal, com extrema parcimônia, harmonizou o primado do respeito ao ato jurídico perfeito com a secular discussão acerca dos efeitos do ato ilegal, admitindo a competência do controle externo para buscar inicialmente que a própria administração suste o contrato, observando-se, é claro, a legislação pertinente. Notese que determinação à sustação não é rescisão, mas apenas ato cautelar impeditivo da consumação da despesa ou do fato gerador de pagamento (execução). A autoridade que recebe a comunicação é que avalia os efeitos da sustação na vida do contrato.

Essa comunicação se faz, como regra, após o atendimento do princípio do contraditório. Embora inexista dispositivo a respeito, parece ser essa a única possibilidade, porque a sustação do contrato afetará obrigações contraídas perante terceiros, muitas vezes não jurisdicionados aos Tribunais de Contas, com os inerentes consectários. Entre esses, cabe apenas lembrar que, na atualidade, a anulação do contrato e até a sua rescisão, mesmo que seja por motivo de interesse público, obrigam a Administração Pública a observar o princípio do contraditório e da ampla defesa. ${ }^{15}$

15 Quando a nulidade é da licitação, essa induz à do contrato, e também deve ser garantido o direito de ampla defesa e do contraditório, conforme art. 49 , caput e $\$ \S 2^{\circ}$ e $3^{\circ}$ da Lei ${ }^{\circ} 8666 / 93$. 
Muito se tem debatido se o Tribunal de Contas deve originariamente assegurar o contraditório ao contratado, conforme o caso, ou se esse dever compete apenas ao órgão jurisdicionado que recebe a determinação para sustar, anular ou rescindir o contrato.

Após o advento da Lei $\mathrm{n}^{\circ} 9.784$ de 29 de janeiro de 1999, com mais ênfase, parece prevalecer o primeiro entendimento, ou seja, deve o próprio Tribunal assegurar a ampla defesa e o contraditório. Desse modo, se analisa o contrato, havendo indícios que possam levar a nulidade, deve o contratado também ser chamado ao processo, pela Corte de Contas.

Nesse sentido é o entendimento do Supremo Tribunal Federal, sintetizado na seguinte ementa:

EMENTA: 1. Tribunal de Contas: competência: contratos administrativos (CF, art. 71, IX e $\S \S 1^{\circ}$ e $2^{\circ}$ ). O Tribunal de Contas da União - embora não tenha poder para anular ou sustar contratos administrativos - tem competência, conforme o art. 71, IX, para determinar à autoridade administrativa que promova a anulação do contrato e, se for o caso, da licitação de que se originou. II. Tribunal de Contas: processo de representação fundado em invalidade de contrato administrativo: incidência das garantias do devido processo legal e do contraditório e ampla defesa, que impõem assegurar aos interessados, a começar do particular contratante, a ciência de sua instauração e as intervenções cabíveis. Decisão pelo TCU de um processo de representação, do que resultou injunção à autarquia para anular licitação e o contrato já celebrado e em começo de execução com a licitante vencedora, sem que a essa sequer se desse ciência de sua instauração: nulidade. Os mais elementares corolários da garantia constitucional do contraditório e da ampla defesa são a ciência dada ao interessado da instauração do processo e a oportunidade de se manifestar e produzir ou requerer a produção de provas; de outro lado, se impõe a garantia do devido processo legal aos procedimentos administrativos comuns, a fortiori, é irrecusável que a ela há de submeter-se o desempenho de todas as funções de controle do Tribunal de Contas, de colorido quase-jurisdicional. A incidência imediata das garantias constitucionais referidas dispensariam previsão legal expressa de audiência dos interessados; de qualquer modo, nada exclui os procedimentos do Tribunal de Contas da aplicação subsidiária da lei geral de processo administrativo federal (Lei 9.784/99), que assegura aos administrados, entre outros, o direito a "ter ciência da tramitação dos processos administrativos em que tenha a condição de interessado, ter vista dos autos (art. $3^{\circ}$, II), formular alegações e apresentar documentos antes da decisão, os quais serão objeto de consideração pelo órgão competente". A oportunidade de defesa assegurada ao interessado há de ser prévia a decisão, não lhe suprindo a falta a admissibilidade de recurso, mormente quando o único admissível é o de reexame pelo mesmo plenário do TCU, de que emanou a decisão. ${ }^{16}$

16 BRASIL. Supremo Tribunal Federal. MS 23550/DF. Relator: Ministro Marco Aurélio 04 de abril de 2001. Diário da Justiça, Brasília, DF, 31. out. 2001, p. 00006. 
Não se deve olvidar, que há entendimento, em linha mais ortodoxa, no sentido de que atos absolutamente nulos prescindem de ampla defesa. ${ }^{17}$

O entendimento mais consentâneo com o novo ordenamento jurídico, porém. é o retratado no acórdão transcrito, fato que deve obrigar os Tribunais de Contas a revisão de alguns procedimentos. De fato, a jurisprudência referida como mais ortodoxa não analisou a competência do Tribunal de Contas, nem se contextualizou ao tema contratos e an advento da Lei $n^{\circ} 9.784 / 99$, como faz o processo cuja ementa de acórdão foi transcrita.

Se a Administração Pública não atender a recomendação, o Tribunal de Contas não tem poder para sustar diretamente.

Entre a determinação do Tribunal de Contas e a promulgação do decreto legislativo que susta o contrato, está a administração obrigada a deixar de executar ou pagar o contrato?

Certamente não, porque a decisão do Tribunal de Contas não é vinculativa neste caso. Somente o decreto legislativo é que obriga o agente público. Nessa linha de entendimento também é o escólio de Eros Roberto Grau. ${ }^{18}$

Diante da recusa da Administração Pública, o Tribunal de Contas deverá comunicar a recalcitrância ao Poder Legislativo, o qual tem a prerrogativa de sustar o contrato diretamente.

Efetivamente, a competência para sustar contratos não integra o elenco daquelas definidas para o Poder Legislativo na Constituição Federal. Tem, porém, o direito - dever de exercê-la, tão somente, após a recusa do órgão que recebe a recomendação do Tribunal de Contas. Não tem, desse modo, competência originária para o exame de contratos, nem pode prescindir do formal exame técnico do Tribunal de Contas, nem a mesma subsistirá se não houver recusa. Confirma-se aí, mais uma vez, que o Tribunal de Contas não é órgão auxiliar do Poder Legislativo, mas, autônomo, na dicção do Supremo Tribunal Federal, e auxilia a função de controle do Congresso Nacional. ${ }^{19}$

Ensina Carlos da Ari Sundfeld, com a argumentação lógica que o destaca, que:

"A fiscalização da regularidade dos contratos administrativos é tarefa do Tribunal de Contas a quem compete - de modo exclusivo- determinar, ao órgão ou entidade, a adoção de providências para a regularização da despesa. Somente após o esgotamento da ação da Corte de Contas, com a caracterização da ilegalidade não corrigida, é que o legislativo poderá agir, sustando o contrato irregular..$^{20}$

17 BRASIL. Supremo Tribunal Federal. RE 224283/SP. Relator: Ministra Ellen Grace setembro de 2001. Diário da Justiça, Brasília, DF, 11. out. 2001.

18 GRAU, Eros Roberto. TRIBUNAL DE CONTAS - DECISÃO - EFICÁCIA. Parecer Revista de Direito Administrativo, v. 210, out/dez. 1997, p. 351-356.

19 Considerando ilegal a sustação direta pelo Poder Legislativo, sem a participação do Tribunal de Conta São Paulo. Tribunal de Justiça do Estado de São Paulo. Administrativo. Apelação n ${ }^{\circ}$ 008.825.5/1-SP Relator: Desembargador Antônio Villen. São Paulo, 20 de janeiro de 1998.

20 SUNDFELD, Carlos Ari. Pode o Legislativo sustar contrato administrativo (CF, art. $71, \S 1^{\circ}$ ) sem a prévia decretação da ilegalidade pelo Tribunal de Contas? 
Lembra, a propósito, que José Afonso da Silva obtempera ser esse controle de natureza política, mas sujeito à prévia apreciação técnico-administrativa do Tribunal de Contas.

$\mathrm{O}$ ato de sustação pelo Poder Legislativo independe de nova e prévia comunicação, porque essa já foi feita pelo Tribunal de Contas e não acatada pela Administração Pública.

Por esse motivo, ao solicitar a sustação ao Poder Legislativo deve o Tribunal de Contas remeter cópia da correspondência que foi enviada anteriormente à Administração Pública, recomendando a sustação do contrato, posto que é um dos requisitos indispensáveis ao exercício da competência daquele.

Quanto ao não atendimento da recomendação de sustação, poderá esse ser provado:

- pela manifestação escrita da autoridade requerida;

- pela prática de atos incompatíveis com o acatamento;

- por provas coligidas pela inspeção ordenada pelo Tribunal de Contas; ou

- pela simples afirmação do Tribunal de Contas ao Poder Legislativo..11

- simultaneamente ao ato de sustação, cabe ao Poder Legislativo "solicitar, de imediato, ao Poder Executivo as medidas cabíveis".

A Constituição Federal coloca em seqüência a comunicação dirigida pelo Tribunal de Contas ao Poder Legislativo, visando sustar o contrato, a solicitação desse ao Poder Executivo para adoção de medidas cabíveis. Que medidas serão estas? Seriam as de sustação? Óbvio que não, vez que, pelo próprio sentido lógico, descabem repeti-las.

Considerando que o Poder Legislativo e o Poder Judiciário também podem firmar contratos administrativos, como explicar que a Constituição Federal tenha se referido à solicitação de medidas cabíveis apenas ao Poder Executivo? À primeira vista, a restrição ao Poder Executivo parece indicar que o Tribunal de Contas só estaria cuidando do não atendimento da determinação pelo Poder Executivo. Ora, se pode haver recalcitrância por parte do executivo, também poderá ocorrer por parte dos demais poderes. Ademais, a expressão medidas cabíveis, aqui requeridas, não se refere a sustação do contrato pelo jurisdicionado, pois a norma superou essa etapa e agora cuida do não atendimento.

As "medidas cabíveis" aqui referidas, e o fato de serem dirigidas apenas ao Poder Executivo, decorrem de que, embora os três poderes e os órgãos autônomos como o Ministério Público e o Tribunal de Contas possam firmar contrato, fazem-no em nome do ente da esfera de governo a que se vinculam.

Assim, o Superior Tribunal de Justiça, por exemplo, o faz em nome da União, pessoa jurídica correspondente; a Assembléia Legislativa de um Estado, em nome desse; a Secretaria de Obras de um Município, em nome do Município.

21 Consultar FERNANDES. Jorge Ulisses Jacoby. Tribunais de Contas do Brasil. Jurisdição e Competência Editora Fórum. 2003. Subtítulo 17.3.2.2.3., Capítulo II, sobre a prova de fatos negativos. 
Por isso, é indispensável que, por meio do órgão jurídico encarregado da representação judicial da unidade, a entidade jurídica esteja apta a adotar as medidas complementares, como a prestação de contas do contrato, as ações de indenização, o arresto de bens, assunção da obra no estado em que se encontra.

Acresce ainda que embora os três poderes e órgãos autônomos tenham competência para gerir recursos, as medidas cabíveis para defesa da Fazenda são titularizadas stricto senso no Poder Executivo.

O Poder Legislativo tem o prazo improrrogável de noventa dias para efetivar o ato de sustação e solicitar as medidas cabíveis, simultaneamente.

O prazo, exageradamente longo. especialmente se estiver subjacente grave lesão às finanças públicas - fato que justificaria o ato extremo da sustação —, não é em verdade, na prática, de apenas 90 dias, vez que são contados na forma do regimento interno das casas parlamentares. Contudo esse entendimento, não é o mais correio, vez que o destinatário do prazo é o Tribunal de Contas. Assim, embora aceitável em outros casos que o prazo seja contado na forma regimental, neste, especificamente, não prevalece aquela regra contando-se o prazo dia-a-dia, tendo por termo inicial, dies a quo, a data de recebimento pelo respectivo poder.

Decorrido esse prazo sem deliberação, o Tribunal de Contas decidirá a respeito.

Com esse comando, a norma desloca para o Tribunal de Contas a competência para sustar o contrato, talvez muito tardiamente, numa tentativa de estabelecer um sistema de freios e contrapesos.

Decidirá a respeito da sustação- que o Poder Legislativo não decidiu- e também das medidas que cabiam ao Poder Executivo adotar e não adotou.

É implícita a competência do Poder Legislativo examinar a impugnação.

$\mathrm{E}$, se o Poder Legislativo decidir que o contrato não padece dos vícios apontados pelo Tribunal de Contas? Neste caso, a competência do Tribunal de Contas para sustar não é reestabelecida porque o constituinte só permitiu o retorno da competência diante da omissão, fruição in albis do prazo.

A sustação deve submeter-se ao princípio da legalidade.

É evidente que o exercício da competência não pode se concretizar com a ofensa às demais garantias do ordenamento jurídico.

Assim, a sustação cautelar ou definitiva não pode afetara garantia constitucional do equilíbrio econômico-financeiro que tem como termo a quo, ou seja. inicial, da data da proposta. ${ }^{22}$ Tal garantia só não prospera se provado que a conduta dolosa do contratado consistiu na elevação arbitrária dos preços. ${ }^{23}$

Se a sustação tiver natureza cautelar e implicar o retardamento da execução, o ato que altera o prazo deve ser justificado e publicado; ${ }^{24}$ se implicar em desmobili-

22 Brasil. Constituição (1988) Constituição da República Federativa do Brasil. Brasilia, DF: Senado, 1988, art. 37, inciso XXI.

23 BRASIL. Lei $n^{\circ} 8.666$ de 21 de junho de 1993. Regulamenta o art. 37. inciso XXI, da Constituição Federal, institui normas para licitaçōes contratos da Administração Pública e dá outras providências. Diário Oficial (da) União, Poder Executivo, Brasília, 22 jun. 1993, art. 96 inciso I. 24 Brasil. Lei $n^{\circ} 8.666$, de 21 junho de 1993. Regulamenta o art. 37, inciso XXI, da Constituição 
zação, o pagamento do custo correspondente para o contratado, nos termos previstos no edital, ${ }^{25}$ se tiver natureza definitiva, as garantias do art. 78 inc. XIV e XV e 79 , da Lei 8.666/93.

Dada a complexidade de que se reveste a sustação de contrato e seus efeitos na órbita jurídica e econômica, o exercício dessa competência deve ser concretizada com extrema parcimônia, avaliando-se os efeitos decorrentes para o erário e a sociedade.

\section{Efeitos do exame pelo Tribunal de Contas}

Um dos instrumentos jurídicos mais comuns para provocar o exame judicial dos atos administrativos é o mandado de segurança. Consabido que para a concessão dessa ação, além dos pressupostos processuais de ordinário, exige-se adicionalmente: a razoabilidade jurídica na pretensão deduzida e o perigo de que a demora na prestação jurisdicional faça perecer ou tornar extremamente oneroso o próprio direito, comumente traduzidos nas expressões fumus boni júris e periculum in mora. Se o Tribunal de Contas examinou o edital, o procedimento licitatório ou o contrato, considerando qualquer deles regular, certamente elimina-se um dos pressupostos do mandado de segurança e até mesmo da concessão da liminar: o fumus boni júris. Isso porque o Tribunal de Contas ao proceder ao exame vai muito além da legalidade: examina ainda legitimidade e a economicidade, controles esses muitas vezes interditos ao exame judicial. ${ }^{26}$

\section{Princípios e diretrizes vetoriais da ação do controle sobre licitação.}

O tema licitação e contratos é bastante complexo. A norma reguladora, conquanto considerada inegavelmente um avanço como instrumento da transparência na gestão pública, possui mais de quinhentos dispositivos, se computados artigos, $\S \S$ e incisos, com deficiência na organização das regras; os servidores públicos guiam-se por doutrinadores que ainda divergem em pontos substanciais; a jurisprudência do Poder Judiciário não é bem compreendida e a do Tribunal de Contas, ainda que abundante, não consegue certa uniformidade ou mesmo atingir a todos os setores que operam a norma. Some-se a isso a inexplicável e sistemática incompetência na gestão da liberação das cotas financeiras do orçamento que concentra a entrega de

Federal, institui normas para licitações e contratos da Administração Pública e dá outras providências. Diário Oficial (da) Uniāo, Poder Executivo, Brasília, 22. Jun., art. 40 inciso X c/c art. 78, inciso XVI.

25 Brasil. Lei $n^{\circ} 8.666$, de 21 de junho de 1993. Regulamenta o art. 37, inciso XXI, da Constituição Federal, institui normas para licitações e contratos da Administração Pública e dá outras providências. Diário Oficial (da) União, Poder Executivo, Brasília, 22. jun. 1993, art. $8^{\circ}$.

26 Nesse sentido: Tribunal Regional Federal//a Região. Al 96.0112689-9/DF, DJU 04.06.1996. 
recursos no final do exercício, sem que ninguém faça cumprir a Constituição Federal que considera tal ato como crime de responsabilidade. ${ }^{27}$

Por todos esses motivos, a atuação do controle deve impor-se com certa parcimônia, admitindo-se à luz do princípio da aderência a diretrizes e normas que o gestor público acolha entre diversas teses juridicamente razoáveis a que melhor agasalhe o interesse público.

\section{I Princípio da aderência a diretrizes e normas}

Um dos princípios vetoriais da ação do controle é o da aderência a diretrizes e normas..$^{28}$

Esse preceito norteia a ação dos agentes de controle de modo a buscar o fiel cumprimento das diretrizes de políticas públicas e acatamento de leis e normas em geral.

Muitas vezes, o agente de controle é tentado a substituir-se ao administrador, confundindo o desempenho de sua função. Ora, é bem provável que um agente de controle seja capaz de encontrar solução melhor do que a que foi aplicada, até porque tem a vantagem de chegar após o fato, aferindo as causas e consequiências da decisão.

Novamente aqui, há estreita correlação entre gerir e controlar, corolário do princípio da segregação das funções.

Quando busca o fiel cumprimento das normas e diretrizes, o órgão de controle também tolera, por dever de lógica, um conjunto de interpretações consideradas, juridicamente, razoáveis e ações que não tiveram o rendimento ótimo, por terem sofrido os efeitos de fatores razoavelmente imprevistos.

A jurisprudência do Tribunal de Contas da União, órgão que constitui o paradigma federal de controle, é, pois, nesse sentido:

a) tese inaugurada com brilhante voto do Ministro Ivan Luz sustenta que quando o Administrador age com base em parecer jurídico bem fundamentado, que adota tese juridicamente razoável, em princípio, não pode ser condenado; ${ }^{29}$

b) a liberdade de gestão não está fora da ação do controle, que deve guiar-se também pelo princípio da razoabilidade. Em relação, por exemplo, a acordo judicial, submetido a exame do TCU, concluiu este que ficou demostrada a pouca possibilidade de êxito, ensejando, pois, julgamento pela regularidade. Asseverou, no caso, o relator que a avaliação jurídica, realizada à época, apontava reduzidas possibilidades

27 Constituição Federal: art. 85, inc. VI.

28 FERNANDES, Jorge Ulisses Jacoby. Tribunais de Contas do Brasil: Jurisdição e Competência. Belo Horizonte: Ed. Fórum, 2003, p.45.

29 BRASIL Tribunal de Contas da Uniāo. Administrativo. Prestação de Contas. Processo TC ${ }^{\circ}$ 25.707/82-5. Interessado Fundação Universidade de Brasília - FUB. Relator: Ministro Ivan Luz, Brasilia, DF, 11 de fevereiro de 1998. Diário Oficial da República Federativa do Brasil. Brasília, DF, 19 jun. 1984. Seção 1. p. 8791: Consulte ainda CAMMAROSANO, Márcio: Da Responsabilidade de autoridades governamentais por atos que expedem tendo por suporte pareceres do judiciário. Informativo de Licitaçōes e Contratos, Curitiba, v. 37, a. IV. p. 228-230. mar. 1997. 
de sucesso dos recursos interpostos pela Companhia, em virtude de decisões pretéritas similares, prolatadas pelo Poder Judiciário; ${ }^{30}$

c) mesmo quando se trata de parecer encomendado pela Administração Pública, os órgãos de controle procedem ao exame da tese sustentada, em respeito à possibilidade de interpretações divergentes. Por outro lado, os órgãos de controle não estão obrigados a acolher a tese, mesmo que subscrita por nomes de expressão; ${ }^{31}$

d) o Tribunal de Contas da União tem por regra não penalizar o agente quando adota, em questão ainda não definida em sua jurisprudência, tese juridicamente razoável. ${ }^{32}$

\subsection{Princípio da ampla defesa e do contraditório}

No Brasil, a Constituição Federal de 1988 assegura aos litigantes em processo judicial ou administrativo, e aos acusados em geral o contraditório e a ampla defesa, com os meios e recursos a ele inerentes. ${ }^{33}$

Nesse subtítulo será estudada apenas a garantia da ampla defesa no que se refere às contas julgadas pelo próprio Tribunal de Contas. A aplicação desse princípio na emissão de parecer prévio, nas contas anuais do Governo, como um todo, e nos demais atos será referido em subtítulos específicos. ${ }^{34}$

O princípio do contraditório, comumente resumido na antiga parêmia latina audiatur et altera pars - consiste na obrigação, do Juiz, em razão de seu dever de imparcialidade, de ouvir a outra parte do processo sobre as alegações deduzidas por uma parte. Também é chamado de princípio da audiência bilateral.

Esse axioma dá sustentação a teoria geral do processo, e sua inobservância acarreta a nulidade do ato, ressalvadas as exceções expressamente admitidas em lei, como a medida liminar sem oitiva da parte adversa, que, por isso mesmo, constitui-se em instrumento restrito.

30 BRASIL. Tribunal de Contas da União. Prestação de Contas. Processo TC $n^{\circ}$ 279.300/93-0. Acórdão nº 8/98. Relator: Ministro José Antônio Barreto de Macedo, Brasília, DF, 11 de fevereiro de 1998. Diário Oficial da República Federativa do Brasil. Brasília. DF, 25 fev. 1998. Seção 1, p. 45.

31 Interessante notar que, neste caso, deveria subsistir o dever de verificar se foram atendidos os requisitos gerais de contratação de pareceristas, estabelecido na Lei de Licitações. É dever indeclinável dos órgãos de controle também verificar esse fato, que na maioria das vezes não apresenta singularidade para justificar a contrataçāo de notórios especialistas. BRASIL. Tribunal de Contas da União. Representação. Processo TC $n^{\circ}$ 625.127/95-1. Ata $n^{\circ}$ 58. Interessado: Secretário de Controle Externo no Estado do Rio Grande do Sul. Relator: Ministro Iram Saraiva, Brasília, DF, 06 de dezembro de 1995. Diário Oficial da República Federativa do Brasil, Brasília, DF, 28 dez. 1995. Seção 1, p. 2249.

32 BRASIL Tribunal de Contas da União. Representação formulada por licitante. Processo TC $n^{\circ}$ 002.521/95-1. Decisão $n^{\circ}$ 326/95. Interessado: Fundação Universidade de Brasília-FUB. Relator: Ministro Homero Santos. Brasília, DF 12 de julho de 1995. Diário Oficial da República Federativa do Brasil. Brasília, DF. 01 ago. 1995. Seção 1, p. 11513.

33 Brasil. Constituição (1998), art. LV Op. Nota de rodapé 24.

34 Consultar no Capítulo III o subtítulo 2.1.14.1, sobre parecer e o devido processo legal. 
Com o descortino superior que lhe é peculiar, obtempera o Dr. João Bonifácio Cabral Jr. que, no Direito comparado, em especial na doutrina alemã, subjazem ao direito de defesa três outros direitos, quais sejam:

\subsection{Direito de informação}

Pelo qual se garante que o interessado, num processo administrativo disciplinar, por exemplo, tenha acesso, a todas as informações relativas ao andamento e aos atos do processo. ${ }^{35}$

\subsubsection{Direito de manifestação}

Pelo qual se garante o direito do interessado de manifestar-se oralmente ou peticionando por escrito no processo.

Nos processos de auditoria é tradição que se reflete nas normas conceder ao auditado a oportunidade de discutir os achados de auditoria. ${ }^{36}$

A operacionalização da discussão se dá, inicialmente, pelo uso da Nota de Auditoria contendo os pontos a serem analisados e esclarecidos pelo auditado. Estes esclarecimentos devem ser prestados, igualmente, por escrito, sendo, no entanto, passível de discussão entre as partes, com vistas a obtenção de uma maior compreensão, de ambos, acerca das questões colocadas.

Ao fim da discussão, deve a equipe de auditoria ter em mãos os esclarecimentos prestados, formalmente, pela auditada acerca dos pontos importantes a serem contemplados no relatório final.

\subsubsection{Direito de ver suas razóes consideradas}

Vale dizer: no caso de uma sindicância ou processo administrativo disciplinar, a comissão, em seu relatório final, não está vinculada a acatar como procedentes as razões de defesa; todavia, isto, está obrigada, sob pena de nulidade, a considerar as razões de defesa, enfrentando-as, quer para acatá-las, quer, principalmente, quando for o caso, para mostrar, fundamentalmente na prova colhida na instrução, a improcedência ou inconsistência das mesmas.

35 Controvérsias existem sobre a possibilidade de vistas fora do Tribunal de Contas pelo interessado ou seu advogado, regularmente constituído. Em sentido afirmativo: Brasil. Supremo Tribunal Federal. Administrativo. Mandado de Segurança $n^{\circ}$ 22.314-6. Relator: Ministro Octávio Gallotti. Brasília, 05 de setembro de 1996. Diário da Justiça, Brasilia, DF, 07 fev. de 1997, p. 01340 e Distrito Federal. Tribunal de Contas do Distrito Federal. Pedido de Retirada de Processo de TCE. Processo $n^{\circ}$ 750/97B. Relator: Conselheiro - Auditor Osvaldo Rodrigues de Souza. Brasília, 22 de abril de 1997. Diário Oficial do Distrito Federal, Brasília, DF, 29 mar. 1997, p. 3033-3039.

36 Achados de auditoria são os desvios significativos identificados aos se comparar situações reais com um critério de auditoria previamente definido. Estão pautados em fatos, atos ou informações significativos, observados durante determinada auditoria. Para que os achados sejam considerados como tal, as evidências ou provas de auditoria devem ser irrefutáveis e objetivas, de modo a servirem de fundamento às conclusões do analista. In: Manual de Auditoria Integrada - Versão I. p. 33/42. 
Desafio relevante consiste a inteligência em avaliar como os princípios da epígrafe afetam os diversos tipos de processos que estão submetidos ao plexo de competência dos Tribunais de Contas.

$\mathrm{O}$ tema desafia a inteligência porque exige profundo conhecimento da natureza das diversas funções que essas cortes exercem e como, quando e em favor de quem devem ser concretizados tais princípios.

\subsection{Diretriz da definição de responsabilidade}

A própria Lei definiu algumas responsabilidades que a jurisprudência vem pouco a pouco reafirmando:

a) a responsabilidade por examinar e aprovar o edital é do órgão jurídico;

b) a responsabilidade por conduzir a licitação é da comissão de licitação, mas é permitido aos respectivos membros ressalvarem seu entendimento quando não concordarem com o dos demais membros, hipótese em que só responderão nos limites dos atos que praticarem;

c) compete a comissão de licitação verificar a compatibilidade dos preços das propostas $^{37}$ com o preço praticado no âmbito da Administração Pública: ${ }^{38}$

d) 0 ato de homologar a licitação, implica na verificação da correção das etapas precedentes e atribui para o homologador a responsabilidade solidária em relação a todos os atos homologados.

\section{Conclusões}

Sinteticamente, podemos apresentar as seguintes conclusões:

$1^{a}$ conclusão:

O Tribunal de Contas pode sustar se não atendido, a execução do ato licitatório quando impugnado.

$2^{\mathrm{a}}$ conclusão:

O Poder Legislativo não possui poder para sustar o ato licitatório, mas pode sustar $\mathrm{o}$ ato normativo que lhe dá suporte, como ocorre com a concessão ou permissão de serviço público.

$3^{\mathrm{a}}$ conclusão:

O Tribunal de Contas pode solicitar edital para exame, mas não se exige aprovação prévia do Tribunal de Contas para a validade do ato.

$4^{\text {a }}$ conclusão:

O Tribunal de Contas pode ordenar a correção de edital e, neste caso, os órgãos ficam obrigados a adotar as medidas corretivas determinadas. 


\section{$5^{\text {a }}$ conclusão:}

A impugnação do ato pode decorrer de representação de licitante, contratado ou pessoa física ou jurídica e, independentemente dessa iniciativa os Tribunais de Contas podem solicitar para exame editais de licitação.

$\sigma^{a}$ conclusão:

A representação ao Tribunal de Contas deve ser fundamentada, indicando a irregularidade na aplicação desta Lei. Mas o Tribunal de Contas não fica adstrito aos motivos alegados.

$7^{a}$ conclusão:

Para os Tribunais de Contas há uma faculdade de pedir determinado edital para exame. Não há previsão legal para determinar a remessa dos editais aos Tribunais de Contas: norma com esse teor fere o princípio elementar de que a área fim (no caso, licitadora) não deve trabalhar para a área meio (no caso, controladora). $\mathrm{O}$ Tribunal de Contas pode pedir seja remetido determinado edital, mas falece competência para generalizar a remessa.

$8^{a}$ conclusão:

O fato do Tribunal de Contas solicitar edital para exame, não implica a suspensão imediata do certame. Se o Tribunal de Contas não delibera expressamente a respeito. fica ao prudente arbítrio da autoridade administrativa suspender o certame para aguardar a decisão do Tribunal de Contas ou não.

$9^{a}$ conclusão:

Qualquer cidadão é parte legítima para impugnar edital de licitação e, independente do exercício desse direito pode representar ao Tribunal de Contas.

$10^{4}$ conclusão:

O licitante que não impugna o edital tempestivamente perante a própria administração, decai do direito de praticar esse ato perante à Administração Pública e ficará prejudicado o exercício da faculdade prevista no art. 113 da Lei $n^{\circ}$ 8.666/93. 